\title{
Gullstandarder er ikke for alle
}

Medisinsk kunnskap utvikler seg raskt hva angår optimale behandlinger, og gullstandarden for behandlingseffektspørsmål er ansett å være randomiserte, kontrollerte studier. Man kan godt like å se den kompliserte, mangfoldige medisinske kunnskapen satt i system på en så flott måte. Men er det alltid pasientens beste som måles?

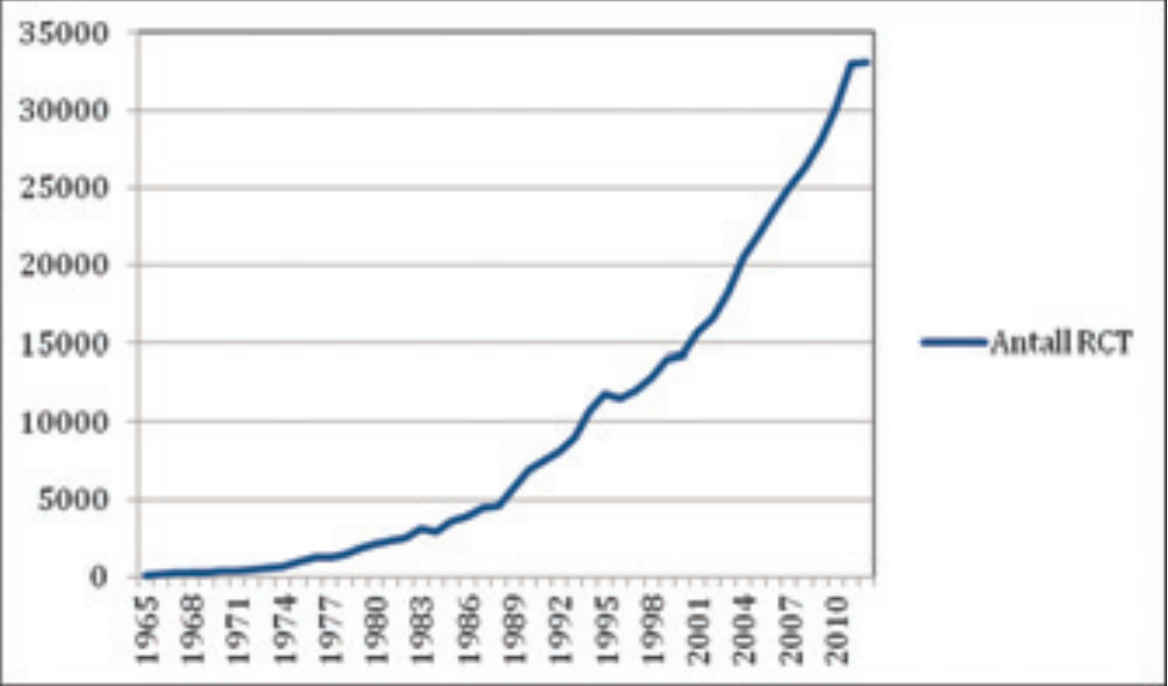

Statistikken over publiserte randomiserte, kontrollerte forsøk viser en rask økning. (c Kaveh Rashidi

En middelaldrende mann legges inn i sykehus med brystsmerter. Man konkluderer med stabil angina pectoris og skriver ham dagen etter ut med acetylsalisylsyre, statin og betablokker. Dette er evidensbaserte medisiner for denne pasientgruppen. Men hva om han har stor glede av krevende toppturer? Hva om han aldri har brukt medisiner fast før og er engstelig? Hva om kollegaen hans fikk leverproblemer av kolesterolsenkende? Dette er faktorer en randomiserte, kontrollerte forsøk (RCT) ikke tar hensyn til. Og målet, som lege, er vel uansett ikke å implementere RCT-er det er å hjelpe den enkelte pasient til et optimalt liv - hva enn det måtte innebære for den enkelte.

Dette er bare ett eksempel. Det finnes nok utallige tilfeller der pasienter har fått råd på grunnlag av studier - uten at man har tatt hensyn til det mennesket pasienten er. Burde vi ta oss mer tid med pasienten før vi hiver på «standardmedisinene»? Burde vi ha oppfølgingssamtaler i primærhelsetjenesten der vi spør hvordan det er å leve med faste medisiner?

Randomiserte, kontrollerte studier er populært Statistikken over publiserte randomiserte, kontrollerte forsøk sier sitt om populari- teten til denne studieformen. Ved å søke i trenddatabasen til Publine (Medline) kan man enkelt få mye informasjon. Her kan man se den kvantitative utviklingen i RCTer over tid (1).

Antallet øker jevnlig, og det er tydelig at vi vil ha mer. Og kanskje enda viktigere: De farmasøytiske selskapene vil ha mer. Det finnes i dag ingen bedre måte å selge medisiner på enn å «bevise» deres nytte ved hjelp av en randomisert, kontrollert studie. Og selv om det å følge resultatene slavisk skaper mange vinnere, tør jeg påstå at det er én stor taper: Ola nordmann.

\section{Overførbarhet}

\section{til den kliniske avgjørelsen}

Resultatene fra en randomisert, kontrollert studie er basert på en spesifikk studiepopulasjon. Det har seg ofte sånn at våre pasienter ikke er sammenliknbare med studiepopulasjonen (2). For hva måler egentlig studiene? Som oftest er det harde endepunkter som dødelighet og alvorlige helsetilstander, eventuelt myke endepunkter som blodtrykk og kolesterolverdi. Men er dette viktigst for pasienten vår?

Pasientens personlige opplevelser av å bruke en spesifikk medisin fortjener større oppmerksomhet. Den enkelte må i større grad få muligheten til å forstå gevinsten
Kaveh Rashidi

kavehrashidi@hotmail.com

Kaveh Rashidi (f. 1988) er turnuslege

ved Kirurgisk avdeling, Bærum sykehus, og lege på Sex og Samfunn i Oslo.

\section{PUBLISERT I BLOGGEN}

(5) 16.1 .2014

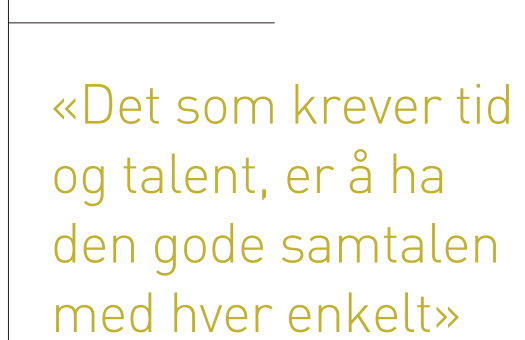

av og risikoen ved medikamentene de bruker, og dette må settes opp mot den subjektive opplevelsen av bruken.

\section{Veien videre}

Jeg synes vi må ha mye større vekt på det kvalitative i medisinering av pasienter. Det er lett å «dobbeltplatehemme» og det er lett å angripe hjertesvikt med vårt flotte arsenal av medikamentelle våpen. Det som krever tid og talent, er å ha den gode samtalen med hver enkelt. Misforstå meg rett: Det er flott at legekulturen har gått fra å være erfaringsbasert til at vi vitenskapeliggjør erfaringene. Men randomiserte, kontrollerte studier er kun et verktøy og må alltid brukes med omhu og refleksjon i forhold til den enkelte pasient.

\section{Litteratur}

1. Alexandru DC. Medline trend: automatedyearlystatisticsofPubMedresults for anyquery, 2004. http://dan.corlan.net/medline-trend.html (21.12014)

2. Guyatt G, Rennie D. Users' guides to the medical literature. JAMA \& Archives Journals, AMA Press, 2002. http://jamaevidence.com/resource/520 (21.1.2014).

Kommentarer til og diskusjoner om innlegget finner du på blogg.tidsskriftet.no Vil du blogge, ta kontakt. 